Article

\title{
Detection and Characterization of Histamine-Producing Strains of Photobacterium damselae subsp. damselae Isolated from Mullets
}

\author{
Marcello Trevisani ${ }^{1, *}$, Rocco Mancusi ${ }^{1}$, Matilde Cecchini ${ }^{1}$, Claudia Costanza ${ }^{1}$ \\ and Marino Prearo ${ }^{2}$ \\ 1 Dipartimento di Scienze Mediche Veterinarie, Università degli Studi di Bologna, Alma Mater Studiorum, \\ via Tolara di Sopra 50, Ozzano Emilia 40064, Italy; mancusirocco@virgilio.it (R.M.); \\ matilde.cecchini@unibo.it (M.C.); claudia.costanza.vet@gmail.com (C.C.) \\ 2 S.S. Laboratorio Specialistico Ittiopatologia, Istituto Zooprofilattico Sperimentale del Piemonte, \\ Liguria e Valle d'Aosta, Torino 10154, Italy; Marino.Prearo@izsto.it \\ * Correspondence: marcello.trevisani@unibo.it; Tel.: +39-051-209-7330
}

Academic Editors: Chrissanthy Papadopoulou, Vangelis Economou and Hercules Sakkas Received: 13 April 2017; Accepted: 13 June 2017; Published: 20 June 2017

\begin{abstract}
Photobacterium damselae subsp. damselae $(P d d)$ is considered to be an emerging pathogen of marine fish and has also been implicated in cases of histamine food poisoning. In this study, eight strains isolated from mullets of the genera Mugil and Liza captured in the Ligurian Sea were characterized, and a method to detect histamine-producing Pdd from fish samples was developed. The histamine-producing potential of the strains was evaluated in culture media (TSB+) using a histamine biosensor. Subsequently, two strains were used to contaminate mackerel fillets ( 4 or $40 \mathrm{CFU} / \mathrm{g}$ ), simulating a cross-contamination on the selling fish stalls. Sample homogenates were enriched in TSB+. The cultures were then inoculated on thiosulfate-citrate-bile salts-sucrose agar (TCBS) and the dark green colonies were cultured on Niven agar. The violet isolates were characterized using specific biochemical and PCR based tests. All Pdd strains were histamine producers, yielding concentration varying from 167 and $8977 \mu \mathrm{g} / \mathrm{mL}$ in TSB+ cultures incubated at $30{ }^{\circ} \mathrm{C}$ for $24 \mathrm{~h}$. Pdd colonies were detected from the inoculated mackerel samples and their histidine decarboxylase gene was amplified using species-specific primer pairs designed for this study. The results indicate that mullets can be source of $P d d$ and the fish retailers needs to evaluate the risk posed by cross-contamination on the selling fish stalls.
\end{abstract}

Keywords: Photobacterium damselae subsp. damselae; histidine decarboxylase; cross contamination; mullets; histamine biosensor

\section{Introduction}

Histamine fish poisoning is among the most common food borne diseases related to fish consumption. Fifty-six of the 71 food borne disease outbreaks $(78.9 \%)$ that have been notified in Europe in 2011 were due to histamine fish poisoning [1]. The risk is correlated with the number and the histidine decarboxylase activity of the contaminating bacteria that grow in the flesh of fishes that are rich of free histidine, such as tuna, mackerel, and bonito.

Bacteria of the genus Photobacterium, i.e., P. damselae subsp. damselae (Pdd) and P. phosphoreum, are strong histamine producers [2-4]. 
Photobacterium damselae subsp. damselae is considered to be an emerging pathogen of marine fish of importance in aquaculture, with a notable increase in its geographical distribution during the last several years [5].

Kanki et al. [2] demonstrated that $P d d$ inoculated on tuna can produce toxic levels of histamine even at $4{ }^{\circ} \mathrm{C}$. These authors observed that $P d d$ displayed the highest performance in accumulating histamine in fish samples stored at refrigeration temperature in comparison with other psychrotolerant marine bacteria, namely P. phosphoreum and Raoultella planticola. They demonstrated that Pdd (strain JCM 8968) can produce more than $500 \mathrm{mg} / \mathrm{kg}$ histamine at $4{ }^{\circ} \mathrm{C}$ in $24 \mathrm{~h}$ and maintain $60 \%$ and $50 \%$ of the initial activity in tuna and dried saury for up to 12 weeks at $-20^{\circ} \mathrm{C}$, respectively. The presence of $P d d$ in the fish that are stored in melting ice or at chilling temperature and even in the de-frozen and processed seafood can thus pose a significant hazard if the contamination is carried on fish species which are rich in free histidine.

The histidine decarboxylase activity of bacteria that are present in fish samples can be assessed in enrichment broth supplemented with histidine using different analytical methods, including immuno-enzymatic (ELISA) tests, chromatographic methods, or bio-sensing devices [3,6-8]. The detection of histamine-producing bacteria (HPB) is possible by plating the fish homogenates on differential grow media, such as the Niven agar plates [9] and the screening of the suspect colonies with PCR assays for the histidine decarboxylase encoding genes [10], but these analytical methods did not allow the isolation of HPB in a number of samples that developed high level of histamine in the enrichment broth supplemented with histidine [7]. Many studies have demonstrated that among HPB there are some species that are not able to grow on the Niven medium and consequently false negative results occur [11]. In order to isolate the halophilic Photobacterium spp., the use of specific culture medium is needed.

There are few studies concerning the histidine-decarboxylase encoding genes of $P$. damselae and P. phosphoreum [11], and the variability of phenotype expression (histidine-decarboxylase activity) [3,4]. Biosensor technology allows fast, cost effective, and specific detection of histamine in seafood spoilage [12] and histamine biosensors can be useful in assessing the microbiological quality of fish. The enzyme diaminoxidase is known to catalyse the conversion of histamine to imidazole acetaldehyde by means of a bi-enzyme system, used by various researchers [13-15]. The co-substrate, molecular oxygen, is reduced to hydrogen peroxide (Equation (1)). The reduction of hydrogen peroxide to water is catalysed by the enzyme peroxidase using potassium hexacyanoferrate(II) (or other redox systems) as the mediator (Equation (2)). The introduction of a mediator in the bi-enzymatic system (DAO/HRP) leads to an acceleration of the electron transfer, a decrease in the applied working potential (the reduction of the mediator is detected at the electrode), and an increase in sensitivity [15-17].

$$
\begin{gathered}
\mathrm{RCH}_{2} \mathrm{NH}_{2}+\mathrm{O}_{2}+\mathrm{H}_{2} \mathrm{O} \rightarrow(\mathrm{DAO}) \rightarrow \mathrm{RCHO}+\mathrm{NH}_{3}+\mathrm{H}_{2} \mathrm{O}_{2} \\
\mathrm{H}_{2} \mathrm{O}_{2}+\mathrm{Fe}(\mathrm{CN})_{6}{ }^{-4} \rightarrow \mathrm{HRP} \rightarrow \mathrm{H}_{2} \mathrm{O}+\mathrm{Fe}(\mathrm{CN})_{6}{ }^{-3}+\mathrm{e}^{-}
\end{gathered}
$$

The working electrode of a potentiostat acts as an oxidant and the oxidation current increases. The aims of this study were to develop a simple and rapid method to detect histamine-producing P. damselae subsp. damselae from fish samples and characterize their histidine decarboxylase activity.

\section{Materials and Methods}

\subsection{Characterization of Pdd Strains}

Eight strains of $P d d$ that have been isolated from different samples of fish of the species Mugil cephalus, Liza aurata, L. ramada, and L. saliens, which were captured at the estuary of the river Magra in the Eastern Ligurian Sea (Bocche di Magra and Fiumaretta, Amelia municipality, La Spezia province, Italy) [18], were used in this study. The isolates were characterized with biochemical tests for their oxidase, catalase, urease activities, and the ability of fermenting glucose and galactose. In addition, the presence of specific target genes ure C and $16 S$ rRNA was assessed by PCR using the primers designed by Osorio et al. [19] (Table 1). 
Table 1. Primers and PCR protocols used for the identification of P. damselae subsp. damselae and its histidine decarboxylase gene.

\begin{tabular}{|c|c|c|c|}
\hline Gene/Primers & Nucleotide Sequences & Thermal Cycling Conditions & Reference \\
\hline ureC & & \multirow{6}{*}{$\begin{array}{c}95^{\circ} \mathrm{C} 4 \mathrm{~min} ; \\
30 \times \\
\left(95^{\circ} \mathrm{C} 60 \mathrm{~s} ; 60^{\circ} \mathrm{C} 60 \mathrm{~s} ; 72{ }^{\circ} \mathrm{C} 40 \mathrm{~s}\right) ; \\
72{ }^{\circ} \mathrm{C} 5 \mathrm{~min}\end{array}$} & \multirow{6}{*}{ Osorio et al., 2000} \\
\hline Ure- $5^{\prime}$ & 5'-TCCGGAATAGGTAAAGCGGG-3' & & \\
\hline Ure-3' & 5'-CTTGAATATCCATCTCATCTGC-3' & & \\
\hline $16 S$ rRNA & & & \\
\hline Car1 & 5'-GCTTGAAGAGATTCGAGT-3' & & \\
\hline Car2 & 5'-CACCTCGCGGTCTTGCTG-3' & & \\
\hline$h d c \mathrm{dp}^{\mathrm{a}}$ & & $95^{\circ} \mathrm{C} 3 \mathrm{~min} ;$ & \multirow{3}{*}{ De Las Rivas et al., 2005} \\
\hline HIS2-F & 5'-AAYTSNTTYGAYTTYGARAARGARGT-3' & $35 \times$ & \\
\hline HIS2-R & 5'-TANGGNSANCCDATCATYTTRTGNCC-3' & $\begin{array}{c}\left(95^{\circ} \mathrm{C} 15 \mathrm{~s} ; 53^{\circ} \mathrm{C} * 30 \mathrm{~s} ; 72^{\circ} \mathrm{C} 40 \mathrm{~s}\right) ; \\
72^{\circ} \mathrm{C} 5 \mathrm{~min}\end{array}$ & \\
\hline$h d c \mathrm{Pdd}{ }^{\mathrm{b}}$ & & $95^{\circ} \mathrm{C} 3 \mathrm{~min} ;$ & \multirow{3}{*}{ (Genebank accession number JCM 8968) } \\
\hline$h d c P d d-F$ & 5'-GGATTAGCGCATGGATTGGT-3' & $30 \times$ & \\
\hline$h d c P d d-R$ & 5'-AACGCCTAAGAAACCCCACA-3' & $\left(95^{\circ} \mathrm{C} 10 \mathrm{~s} ; 60{ }^{\circ} \mathrm{C} 45 \mathrm{~s}\right)$ & \\
\hline
\end{tabular}


In order to detect the histidine decarboxylase gene of $P$. damselae subsp. damselae two primer pairs were used. The primers HIS2-F and HIS2-R designed by De Las Rivas et al. [10] allow the amplification of a specific 531-bp DNA fragment from gram-negative histamine-producing bacteria including P. damselae, strain CECT 626T (ATCC 33539) [20].

In this study, target-specific primers for $P d d$ were designed to be specific for Genbank accession AB259289.1 (HDC, Histidine decarboxylase gene of Photobacterium damselae (strain JCM 8968)) [2]. The designed PCR primers ( $h d c P d d$, Table 1) were checked for specificity with Primer-Blast software (NCBI, Cambridge, UK).

\subsection{DNA Extraction and PCR Procedures}

Strains were grown on Tryptone Soy Agar (TSA, Thermofisher, Milano, Italy) supplemented with $\mathrm{NaCl}(2 \%)$ at $25^{\circ} \mathrm{C}$ for $48 \mathrm{~h}$. Two colonies were randomly picked for each strain using a sterile toothpick and the DNA was extracted by boiling suspensions of cells in a 5\% suspension of Chelex 100 (Bio-Rad Laboratories, Hercules, CA, USA) following the producer protocol.

Real-Time PCR was performed on a MiniOpticon Real-Time PCR System (Bio-Rad Laboratories) using SsoFast EvaGreen Supermix (Bio-Rad). Total reaction volume of $20 \mu \mathrm{L}$ included: $300 \mathrm{nM}$ of each forward and reverse primers, $1 \mu \mathrm{L}$ of template DNA and the SsoFast EvaGreen Supermix (according to the manufacturer's instructions). Each run included a non-template control (NTC). Two laboratory reference strains characterized as Morganella morganii and Photobacterium damselae subsp. damselae in accordance with their colony characteristics, biochemical tests (API20E and API20NE systems) and genetic characterization were used as positive controls [19,21]. Real-time amplification for each gene, including controls and samples, was performed in duplicate under identical PCR conditions. Thermal cycle was set as reported in Table 1 . At the end of the PCR cycles, a melting curve was conducted between $65^{\circ} \mathrm{C}$ and $95^{\circ} \mathrm{C}$ with a $0.5^{\circ} \mathrm{C} / 5 \mathrm{~s}$ increment read and continuous fluorescence measurement. The effect of annealing temperature was analyzed using gradient PCR amplification in the range from 49 to $53{ }^{\circ} \mathrm{C}$.

\subsection{Assay for Histamine Production: A Biosensor Fabrication}

To confirm histamine production by each HPB isolate, single colonies were suspended in Tryptone Soy Broth (Thermofisher, Milano, Italy) supplemented with $\mathrm{NaCl}(2 \%)$ and L-Histidine hydrochloride (1\%) (Sigma-Aldrich, Milano, Italy) (TSB+) and incubated at $30{ }^{\circ} \mathrm{C}$ for $24 \mathrm{~h}$. After the incubation, the cultures were sterilized at $121^{\circ} \mathrm{C}$ for $15 \mathrm{~min}$ and the supernatant was used for histamine quantitative detection.

To comparatively assess histamine production ability of each strain, the microbial suspensions were diluted with TSB+ to have $40 \%$ optical density at $540 \mathrm{~nm}$, corresponding to approximately $10^{8} \mathrm{CFU} / \mathrm{mL}$. The concentration of bacteria was subsequently assessed by plating the appropriate dilutions on Tryptone Soy Agar (TSA, Thermofisher, Milano, Italy) with $2 \% \mathrm{NaCl}$.

Quantitative detection of histamine in the enriched broth cultures and standardized microbial suspensions was made using an amperometric enzymatic biosensor. The histamine biosensor is based on the co-immobilization diamine-oxidase (DAO, from Porcine Kidney, $0.11 \mathrm{U} / \mathrm{mg}$ ) and peroxidase (HRP, from horseradish, $25 \mathrm{KU} / \mathrm{mg}$ ) (Sigma-Aldrich, Milano, Italy) on the surface of a glassy carbon electrode (diameter $3 \mathrm{~mm}$, BAS, West Lafayette, IN, USA). The enzymes were immobilized by chemical cross-linking with glutaraldehyde (GA, 25\%) and bovine serum albumin (BSA, fraction V, purity 96-99\%). All reagents were purchased from Sigma-Aldrich (Milano, Italy). Briefly, 10 mg of DAO, $6 \mathrm{mg}$ of HRP and $4 \mathrm{mg}$ of BSA were dissolved in $100 \mu \mathrm{L}$ of Phosphate Buffer (PB, 0.1 M Ph = 7.4). Five $\mu \mathrm{L}$ of GA diluted in water $(2.5 \%)$ were mixed with $15 \mu \mathrm{L}$ of the DAO-HRP-BSA solution. Ten $\mu \mathrm{L}$ of the final solution was put on the cleaned surface of the working electrode and allowed to dry for $30 \mathrm{~min}$ at $25^{\circ} \mathrm{C}$. After the BSA enzyme solution were cross-linked with GA and a consistent gel has developed on the electrode surface, the enzymatic sensor was washed in PB and stored in the same medium at refrigeration temperature. 
The response of the biosensor to the histamine concentration in the bacterial cultures was calculated as the difference between the amperometric signal in inoculated and non-inoculated medium. The values were recorded in millivolts by a potentiostat (Metrhom Autolab PGSTAT10, EcoChemie, Utrecht, The Netherlands) connected to a personal computer using the Autolab GPES 4.9 software. The calibration data was obtained with a series of standard histamine solutions $(1,2,4,6,8,10$, and 20 ppm) were fitted using the software Excel (Microsoft, Redmond, WA, USA). The concentration of histamine in the enriched cultures was calculated by interpolation of the amperometric responses for the samples into the calibration plot constructed with histamine standards.

\subsection{Detection of Pdd from Fish Samples}

A procedure to detect $P d d$ in fish was developed and tested. With this aim mackerel samples were inoculated in duplicate with two $P d d$ strains that produced more than $1000 \mu \mathrm{g} / \mathrm{mL}$ of histamine in TSB+ culture incubated at $30{ }^{\circ} \mathrm{C}$ for $24 \mathrm{~h}$ (high HPB). The test were carried out independently with each of the two strains. Fresh mackerels were purchased from the market and samples (25 g) were inoculated with either $100 \mu \mathrm{L}$ of $P d d$ suspensions standardized to approximately $10^{3}$ and $10^{4}$ $\mathrm{CFU} / \mathrm{mL}$ (4 and $40 \mathrm{CFU} / \mathrm{g}$ ) and control samples (taken from the same mackerels) were analyzed in parallel (controls).

The samples were homogenized $(1: 10 \mathrm{w} / \mathrm{v})$ in TSB+ and the contaminating bacteria were enriched at $25{ }^{\circ} \mathrm{C}$ for $48 \mathrm{~h}$ and subsequently plated on thiosulfate-citrate-bile salts-sucrose agar (TCBS, Thermofisher, Milano, Italy). Dark green colonies with smooth edges were picked and inoculated on plates of modified Niven Agar [9]. Isolated purple colonies developed within $48 \mathrm{~h}$ (suspect $\mathrm{HPB}$ ) were picked and seeded on TSA with $2 \% \mathrm{NaCl}$.

Isolates were analyzed for the oxidase activity (oxidase detection strips Oxoid, Thermofisher, Milano, Italy) and by Gram stain, then the Gram-oxidase positive strains were characterized for the ability to ferment glucose and galactose and the urease activity with the API 20E kit (bioMérieux Italia, Bagno di Ripoli, FI, Italy). DNA of the strains that gave positive reactions was extracted by boiling suspensions of cells in a 5\% suspension of Chelex 100 (Bio-Rad Laboratories) following the producer protocol. DNA extracts were analyzed to detect the presence or absence of specific nucleotide sequence of the genes ureC e $16 S$ rRNA of Pdd by using the PCR protocols described (Table 1).

\section{Results}

All the strains isolated from the fish of the genera Mugil and Liza captured in the Ligurian Sea grew on TCBS producing dark green colonies with smooth edges, tested positive at the glucose, galactose, and urease tests, and produced typical amplicons after PCR, with melting temperatures $(\mathrm{Tm})$ of $84^{\circ} \mathrm{C}$ and $86^{\circ} \mathrm{C}$ for the genes ure $\mathrm{C}$ and $16 S \mathrm{rRNA}$, respectively. The primers his 1 and his 2 produced positive PCR tests only with three of the eight strains analyzed and the level of amplification (cycle threshold, $\mathrm{Ct}$ values was higher than 33). The Tm of the amplicons of $P d d$ was $80^{\circ} \mathrm{C}$ and was different from the amplicon produced by M. morganii $\left(\operatorname{Tm} 84.5^{\circ} \mathrm{C}\right.$ ) (Figure 1). The level of amplification improved when the annealing temperature of PCR was reduced from 53 to $49^{\circ} \mathrm{C}$ and amplicon melting temperature remained at $80{ }^{\circ} \mathrm{C}$ for $P d d$ strains.

All the strains produced good amplification levels by using the primers couple HDCPdd designed for this study and the PCR amplicons produced had a melting temperature of $80.5^{\circ} \mathrm{C}$ (Figure 2).

Molecular sequence analysis with BLAST software were used to compare the HDCPdd primers sequences with the genomes of Gram-bacteria. The primers showed $100 \%$ similarity with a known nucleotide sequence of $P d d$ histidine decarboxylase gene and no similarity with other known sequences of Gram-bacteria. 


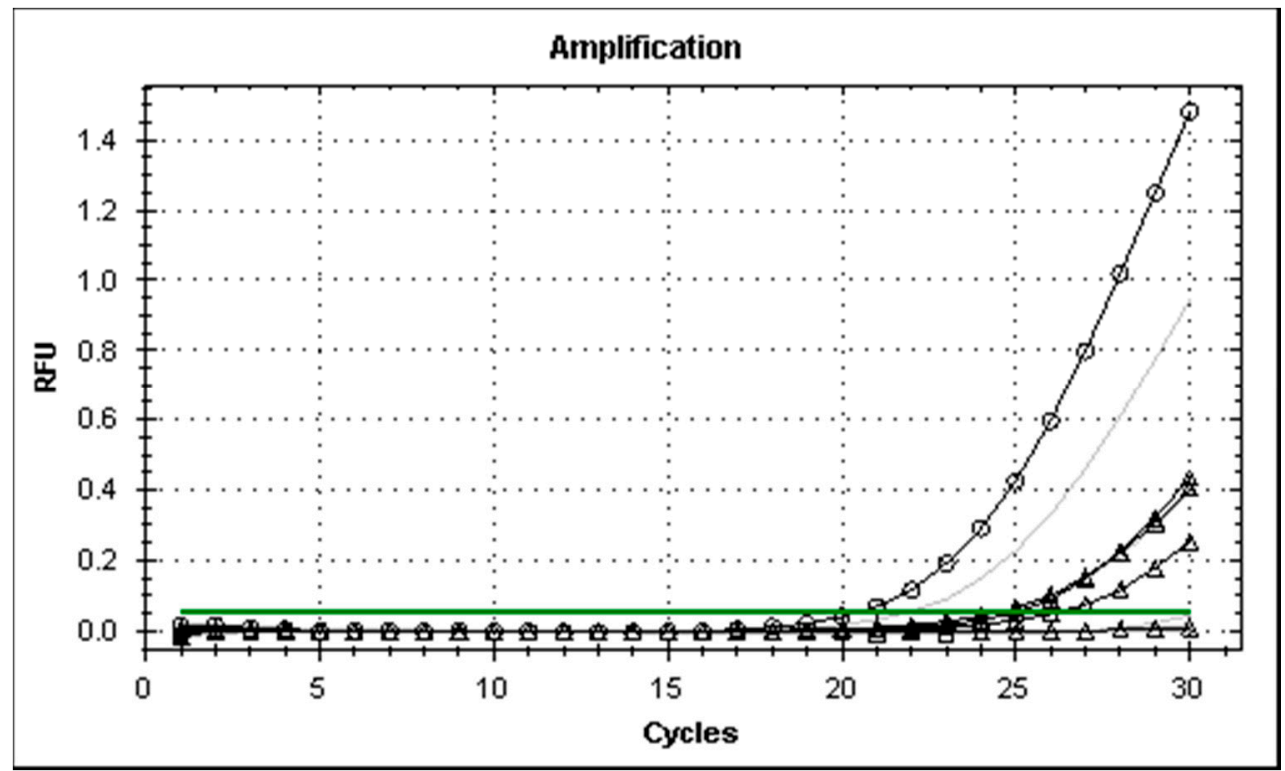

(A)

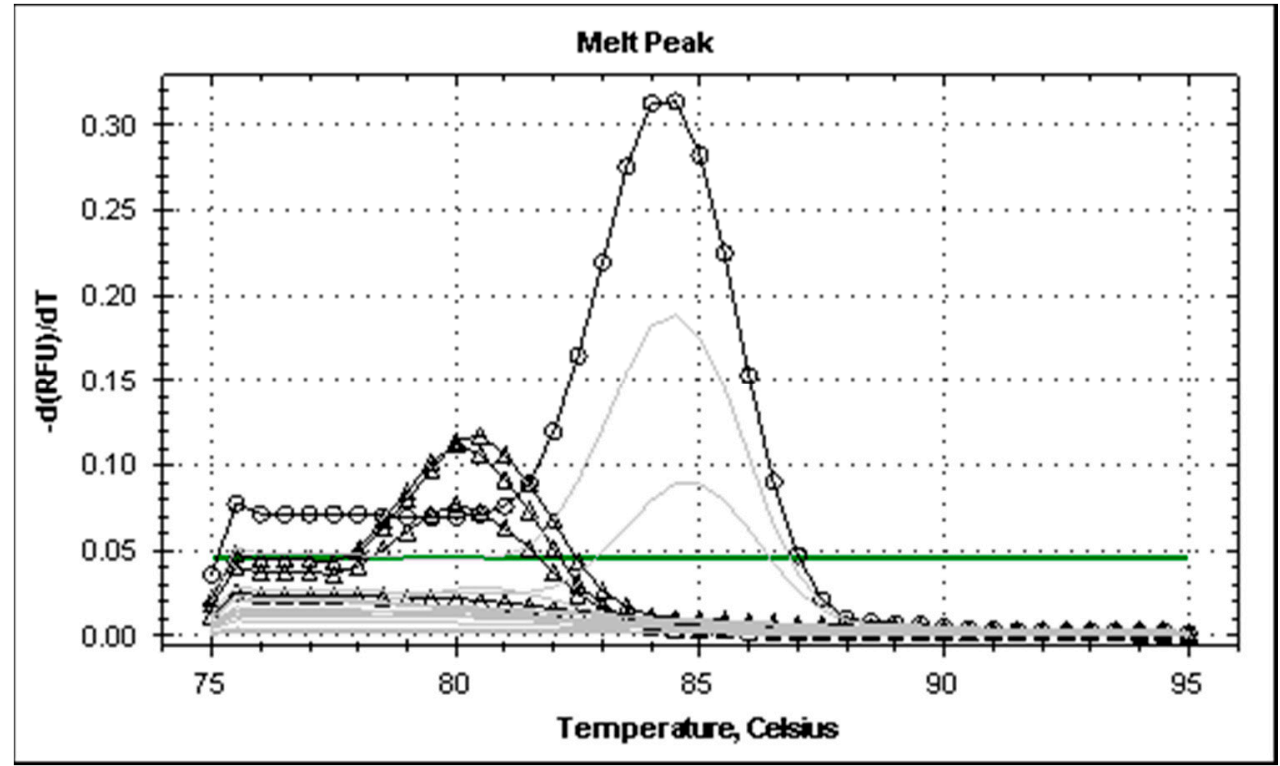

(B)

Figure 1. Amplification plot (A) and melt curves (B) from rt-PCR of histidine decarboxylase genes of Gram-negative bacteria (primers hdc-dp). Legend: annealing temperature for gradient PCR amplification ranged from 49 (dark lines) to $53{ }^{\circ} \mathrm{C}$ (grey lines); lines with symbols $\Delta$ and $\bigcirc$ correspond to $P d d$ (3 strains)and M. morgani, respectively.

All these strains gave positive results with the assay for histamine production in TSB + at $30{ }^{\circ} \mathrm{C}$. The concentration of histamine produced in $24 \mathrm{~h}$ was between 167 and $8977 \mu \mathrm{g} / \mathrm{mL}($ median $=1053)$.

Histamine producing $P d d$ strains were isolated from all the inoculated samples and typical colonies can be easily detected and characterized using the procedure described even at the lower concentration (4 CFU/g) used in this study. Other Gram-bacteria, subsequently identified as Proteus spp., grew on the TCBS and also on the Niven plates, but they did not show swarming behavior. The colonies on the TCBS plates were green, but not dark as those of Pdd. The PCR and biochemical assays can easily discriminate the $P d d$ strains. 


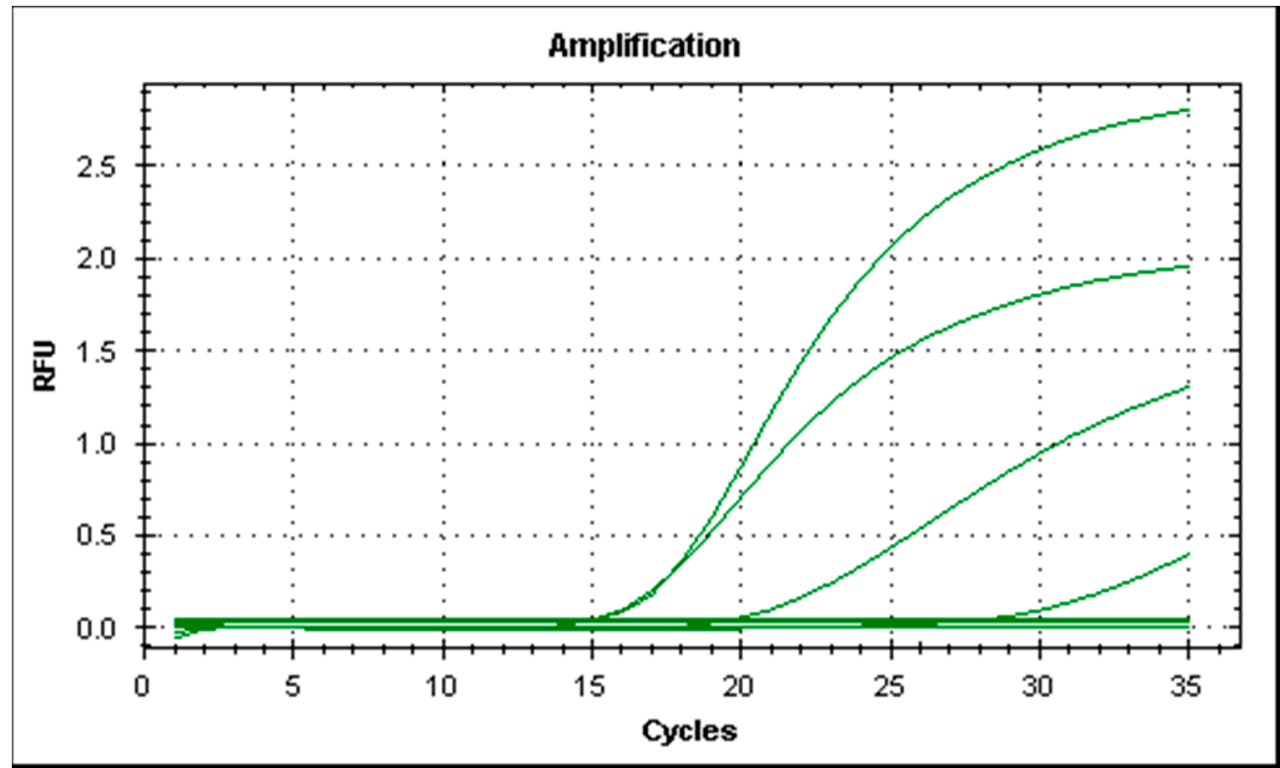

(A)

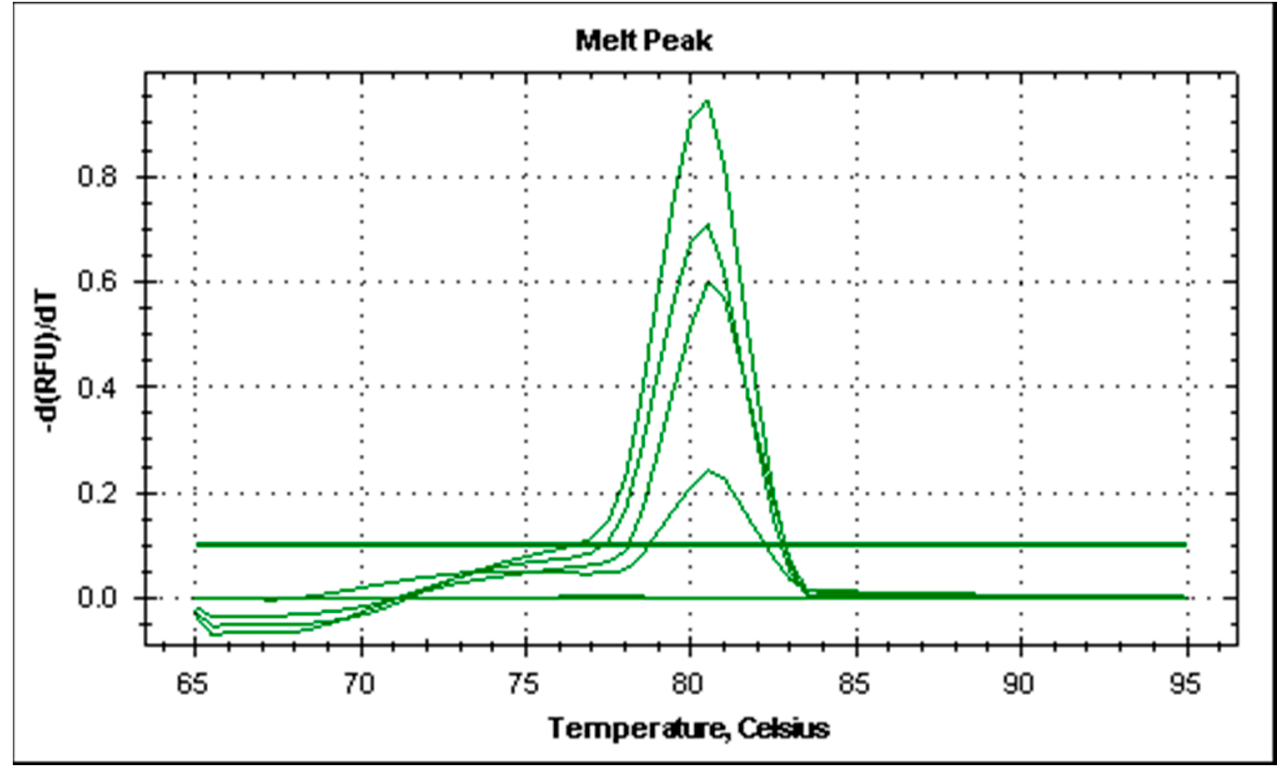

(B)

Figure 2. Amplification plot (A) and melt curves (B) from rt-PCR of histidine decarboxylase gene of Photobacterium damselae subsp. damselae.

\section{Discussion}

Contamination of fish meat with histamine-producing bacteria that can grow at refrigeration temperature pose a risk for the marine species that have high concentration of free histidine.

The presence of psychrototrophic bacteria that are strong producers of histamine of the genus Morganella, Photobacterium e Raoultella was observed in fish during surveys or in the many outbreaks of intoxication [22-24]. Their presence has been frequently detected also in surveys carried out in the Italian fish market $[7,25]$.

Photobacterium damselae subsp. damselae do not grow at the temperature of melting ice, but their role in accumulation of histamine in tuna and dried saury was clearly documented and was correlated to the high stability of its histidine decarboxylase also in defrozen and dried fish [2] and can persist even 
if its viability is reduced [21]. Recent studies have reported a notable increase in the Pdd geographical distribution during the last several years, especially in marine aquaculture $[5,26]$.

Contamination can occur after the harvest, due to manipulations, and during processing. Development of histamine is favored by the spread of bacteria and HDC resulting from the loss of integrity and the post mortem decay of natural barriers (skin, gut, and gills). The risk of histamine (scombroid) intoxication is correlated with the number of HPB and their enzymatic activity of the microbial species, other than to the temperature and time $[27,28]$.

The screening of fish samples to detect HPB and characterize their HDC activity is of utmost importance for the food business operators $(\mathrm{FBO})$ and the food safety authorities that verify the effectiveness of the FBO's controls [29,30].

Differential culture method [9], conductance method [31], and also culture independent Real-Time PCR Method [32] have been used to detect and quantify HPB. Immunological and chromatographic methods, and also biosensors, can be used to measure the histamine produced in the culture media and distinguish the phenotype of HPB strains (i.e., strong or weak histamine producers). Biosensors offer a cheaper alternative to the immunoenzymatic methods [2] or HPLC [3]. The specific detection of HPB strains is needed to characterize the risk, but many studies have reported that the detection of HPB from enriched samples that have tested positive by the assays for histamine can be hampered by the use of the Niven differential culture media, which do not allow the growth of strict halophilic species or other species which are sensitive to its low $\mathrm{pH}$, producing a number of false negative results $[4,7,33]$. In addition, Niven medium is not selective, producing false positive isolates that must be subsequently discriminated by PCR assays or labelled DNA probes for the $h d c$ gene $[4,10,34]$.

Multiple primers sets have been reported for amplification of the histidine decarboxylase gene from Gram-negative bacteria [10,33], but this study has revealed that the degenerate primers designed by De Las Rivas et al. [10] to amplify several similar genetic sequences of the Gram-hdc gene do not give a good performance with the Pdd strains analyzed in this study. A PCR amplification was obtained only by lowering annealing temperature, thus allowing primers with many mismatches with templates to provide amplification [35].

In order to detect $P d d$ from fish samples that have tested strongly positive by the assays for histamine, the use of a selective and differential medium like TCBS in combination with the Niven medium for the selective detection of HPB allowed improvement of the performance of the detection method and the presence of $P d d$ can be confirmed by a PCR assay targeted toward the species-specific sequence of $h d c$ gene.

An excellent correlation between the histamine amount values obtained with biosensors and the histamine amount values obtained by ELISA (enzyme-linked immunosorbent assay ) and HPLC has been established $[14,36,37]$. Therefore, its use for screening purpose is suitable to analyze the sample enrichments and detect those contaminated with strong HPB active at low or ambient temperatures. Nevertheless, comparative analysis of HPB are usually carried out at $30^{\circ} \mathrm{C}$ for $24 \mathrm{~h}$ and the $P d d$ isolates can be categorized as high histamine ( $>1000 \mathrm{ppm}$ ) producers (three strains), intermediate (501 to $999 \mathrm{ppm}$ ) histamine producers (four strains), and low histamine (126 to $500 \mathrm{ppm}$ ) producer (one strain) [3].

The widespread distribution of $P$. damselae subsp. damselae was reported in farmed fish in Spain (Pagrus auriga) [38] and South-eastern Black Sea (Dicentrarchus labrax) [5] where it has been associated with high mortalities. Sea bream and sea bass or mullet are not fish species implicated in histamine poisoning cases, but these farmed fishes are commonly exposed on the selling fish stalls close to tuna and mackerel fillets and manipulated, and even the ice used in the stalls has been reported to be contaminated with HPB [39].

\section{Conclusions}

Fish retailers and other operators should review the risk management practices employed throughout the fish processing chain in relation to controlling histamine formation in at-risk fish species and consider that other fish species, such as mullets of the genera Mugil and Liza, can be 
considered potential carriers of Pdd. Therefore, they must ensure good hygienic practices to prevent cross contamination.

Acknowledgments: We wish to thank the Ictiopathology Laboratory of the Istituto Zooprofilattico Sperimentale del Piemonte, Liguria e Valle d'Aosta for supplying Photobacterium damselae strains.

Author Contributions: Marcello Trevisani conceived, designed the experiments, wrote the paper, contributed reagents/materials/analysis tools and analyzed the data; Rocco Mancusi performed the microbiological experiments and designed the set of primers for PCR detection of P. damselae; Matilde Cecchini performed the analysis for quantification of histamine; Claudia Costanza helped in the microbiological experiments; Marino Prearo provided the Pdd strains and helped reviewing the paper.

Conflicts of Interest: The authors declare no conflict of interest.

\section{References}

1. European Food Safety Authority (EFSA); European Centre for Disease Prevention and Control (ECDC). The European Union Summary Report on Trends and Sources of Zoonoses, Zoonotic Agents and Food-Borne Outbreaks in 2011. EFSA J. 2013, 11, 3129.

2. Kanki, M.; Yoda, T.; Tsukamoto, T.; Baba, E. Histidine Decarboxylases and Their Role in Accumulation of Histamine in Tuna and Dried Saury. Appl. Environ. Microbiol. 2007, 73, 1467-1473. [CrossRef] [PubMed]

3. Bjornsdottir, K.; Bolton, G.E.; McClellan-Green, P.D.; Jaykus, L.-A.; Green, D.P. Detection of Gram-Negative Histamine-Producing Bacteria in Fish: A Comparative Study. J. Food Prot. 2009, 72, 1987-1991. [CrossRef] [PubMed]

4. Björnsdóttir-Butler, K.; Bolton, G.E.; Jaykus, L.A.; McClellan-Green, P.D.; Green, D.P. Development of Molecular-Based Methods for Determination of High Histamine Producing Bacteria in Fish. Int. J. Food Microbiol. 2010, 139, 161-167. [CrossRef] [PubMed]

5. Terceti, M.S.; Ogut, H.; Osorio, R. In the Black Sea: Evidence of a Multiclonal Origin. Appl. Environ. Microbiol. 2016, 82, 3736-3745. [CrossRef] [PubMed]

6. Chen, H.C.; Kung, H.F.; Chen, W.C.; Lin, W.F.; Hwang, D.F.; Lee, Y.C.; Tsai, Y.H. Determination of Histamine and Histamine-Forming Bacteria in Tuna Dumpling Implicated in a Food-Borne Poisoning. Food Chem. 2008, 106, 612-618. [CrossRef]

7. Costanza, C.; Cecchini, M.; Mancusi, R.; Mosso, A.; Giani, G.; Rosmini, R.; Trevisani, M. Evaluation and Identification of Histamine-Forming Bacteria on Fish Products of Middle Adriatic Sea. Ital. J. Food Saf. 2013, 1, 17-20. [CrossRef]

8. Marcobal, A.; De Las Rivas, B.; Muñoz, R. Methods for the Detection of Bacteria Producing Biogenic Amines on Foods: A Survey. J. Verbraucherschutz Lebensmittelsicherheit 2006, 1, 187-196. [CrossRef]

9. Mavromatis, P.; Quantick, P.C. Modication of Niven's Medium for the Enumeration of Histamine-Forming Bacteria and Discussion of the Parameters Associated with Its Use. J. Food Prot. 2002, 65, 546-551. [CrossRef] [PubMed]

10. De Las Rivas, B.; Marcobal, Á.; Muñoz, R. Improved Multiplex-PCR Method for the Simultaneous Detection of Food Bacteria Producing Biogenic Amines. FEMS Microbiol. Lett. 2005, 244, 367-372. [CrossRef] [PubMed]

11. Landete, J.M.; De las Rivas, B.; Marcobal, A.; Muñoz, R. Updated Molecular Knowledge about Histamine Biosynthesis by Bacteria. Crit. Rev. Food Sci. Nutr. 2008, 48, 697-714. [CrossRef] [PubMed]

12. Male, K.B.; Bouvrette, P.; Luong, J.H.T.; Gibbs, B.F. Amperometric Biosensor for Total Histamine, Putrescine and Cadaverine Using Diamine Oxidase. J. Food Sci. 1996, 61, 1012-1016. [CrossRef]

13. Niraj, M.M.G.; Pandey, S. Histamine Biosensor: A Review. Int. J. Pharm. Sci. Res. 2012, 3, 4158-4168.

14. Pérez, S.; Bartrolí, J.; Fàbregas, E. Amperometric Biosensor for the Determination of Histamine in Fish Samples. Food Chem. 2013, 141, 4066-4072. [CrossRef] [PubMed]

15. Tombelli, S.; Mascini, M. Electrochemical Biosensors for Biogenic Amines-A Comparison between Different Approaches. Anal. Chim. Acta 1998, 358, 277-285. [CrossRef]

16. Grieshaber, D.; Mackenzie, R.; Vörös, J.; Reimhult, E. Electrochemical Biosensors-Sensor Principles and Architectures. Sensors 2008, 8, 1400-1458. [CrossRef] [PubMed]

17. Rondeau, A.; Larsson, N.; Boujtita, M.; Gorton, L.; El Murr, N. The Synergetic Effect of Redox Mediators and Peroxidase in a Bienzymatic Biosensor for Glucose Assays in FIA. Analusis 1999, 27, 649-656. [CrossRef] 
18. Serracca, L.; Ercolini, C.; Rossini, I.; Battistini, R.; Giorgi, I.; Prearo, M. E Photobacterium Damselae Subsp. Piscicida in Cefali Del Fiume Magra (Italia) Detection of Photobacterium Damselae Subsp. Damselae and Photobacterium Damselae Subsp. Piscicida in Mullets Caught in the Magra River (Italy). Ittiopatologia 2009, $6,221-228$.

19. Osorio, C.R.; Toranzo, A.E.; Romalde, J.L.; Barja, J.L. Multiplex PCR Assay for ureC and 16S rRNA Genes Clearly Discriminates between Both Subspecies of Photobacterium Damselae. Dis. Aquat. Org. 2000, 40, 177-183. [CrossRef] [PubMed]

20. Landete, J.M.; de las Rivas, B.; Marcobal, A.; Muñoz, R. Molecular Methods for the Detection of Biogenic Amine-Producing Bacteria on Foods. Int. J. Food Microbiol. 2007, 117, 258-269. [CrossRef] [PubMed]

21. Podeur, G.; Dalgaard, P.; Leroi, F.; Prévost, H.; Emborg, J.; Martinussen, J.; Hansen, L.H.; Pilet, M.F. Development of a Real-Time PCR Method Coupled with a Selective Pre-Enrichment Step for Quantification of Morganella Morganii and Morganella Psychrotolerans in Fish Products. Int. J. Food Microbiol. 2015, 203. [CrossRef] [PubMed]

22. Lin, C.S.; Kung, H.F.; Lin, C.M.; Tsai, H.C.; Tsai, Y.H. Histamine Production by Raoultella Ornithinolytica in Mahi-Mahi Meat at Various Storage Temperatures. J. Food Drug Anal. 2016, 24, 305-310. [CrossRef]

23. Emborg, J.; Dalgaard, P. Formation of Histamine and Biogenic Amines in Cold-Smoked Tuna: An Investigation of Psychrotolerant Bacteria from Samples Implicated in Cases of Histamine Fish Poisoning. J. Food Prot. 2006, 69, 897-906. [CrossRef] [PubMed]

24. Kanki, M.; Yoda, T.; Ishibashi, M.; Tsukamoto, T. Photobacterium Phosphoreum Caused a Histamine Fish Poisoning Incident. Int. J. Food Microbiol. 2004, 92, 79-87. [CrossRef] [PubMed]

25. Mancusi, R.; Bini, R.M.; Cecchini, M.; Delle Donne, G.; Rosmini, R.; Trevisani, M. Presenza D'istamina Nei Prodotti Ittici in Commercio. Ital. J. Food Saf. 2012, 1, 35-39. [CrossRef]

26. Rivas, A.J.; Lemos, M.L.; Osorio, C.R. Photobacterium Damselae Subsp. Damselae, a Bacterium Pathogenic for Marine Animals and Humans. Front. Microbiol. 2013, 4, 1-6. [CrossRef] [PubMed]

27. Agence Nationale de Sécurité Sanitaire de L'Alimentation, de L'Environnement et du Travail. Caractéristiques et Sources de L'histamine. In Fiches de Dangers Biologiques Transmissibles par les Aliments "Histamine"; ANSES: Maisons-Alfort Cedex, France, 2012; Available online: https://www.anses.fr/fr/ system/files/MIC2010sa0261.pdf (accessed on 8 June 2017).

28. Canadian Food Inspection Agency. Lookup Results of CFIA Fish List; Canadian Food Inspection Agency: Ottawa, ON, Canada, 2016; Available online: http://www.inspection.gc.ca/active/scripts/fssa/fispoi/ fplist/fpresults.asp?lang=e\&q=\&cmbIn=e\&cbShowAll=on (accessed on 8 June 2017).

29. Hwang, C.C.; Kung, H.F.; Lin, C.S.; Hwang, D.F.; Tsai, Y.H. Bacteriological Quality and Histamine-Forming Bacteria Associated with Fish Meats and Environments in HACCP and Non-HACCP Fish Processing Factories. Food Control 2011, 22, 1657-1662. [CrossRef]

30. Hungerford, J.M. Scombroid Poisoning: A Review. Toxicon 2010, 56, 231-243. [CrossRef] [PubMed]

31. Dalgaard, P.; Mejlhom, O.; Huss, H.H. Conductance Method for Quantitative Determination of Photobacterium Phosphoreum in Fish Products. J. Appl. Microbiol. 1996, 81, 57-64.

32. Macé, S.; Mamlouk, K.; Chipchakova, S.; Prévost, H.; Joffraud, J.J.; Dalgaard, P.; Pilet, M.F.; Dousset, X. Development of a Rapid Real-Time PCR Method as a Tool to Quantify Viable Photobacterium Phosphoreum Bacteria in Salmon (Salmo Salar) Steaks. Appl. Environ. Microbiol. 2013, 79, 2612-2619. [CrossRef] [PubMed]

33. Takahashi, H.; Kimura, B.; Yoshikawa, M.; Fujii, T. Cloning and Sequencing of the Histidine Decarboxylase Genes of Gram-Negative, Histamine-Producing Bacteria and Their Application in Detection and Identification of These Organisms in Fish. Appl. Environ. Microbiol. 2003, 69, 2568-2579. [CrossRef] [PubMed]

34. Wongsariya, K.; Bunyapraphatsara, N.; Yasawong, M. Development of Molecular Approach Based on PCR Assay for Detection of Histamine Producing Bacteria. J. Food Sci. Technol. 2016, 53, 640-648. [CrossRef] [PubMed]

35. Green, S.J.; Venkatramanan, R.; Naqib, A. Deconstructing the Polymerase Chain Reaction: Understanding and Correcting Bias Associated with Primer Degeneracies and Primer-Template Mismatches. PLoS ONE 2015, 10, e0128122. [CrossRef] [PubMed]

36. Apetrei, I.M.; Apetrei, C. Amperometric Biosensor Based on Diamine Oxidase/platinum Nanoparticles/graphene/chitosan Modified Screen-Printed Carbon Electrode for Histamine Detection. Sensors 2016, 16, 422. [CrossRef] [PubMed] 
37. Keow, C.M.; Bakar, F.A.; Salleh, A.B.; Heng, L.Y.; Wagiran, R.; Siddiquee, S. Screen-Printed Histamine Biosensors Fabricated from the Entrapment of Diamine Oxidase in a Photocured poly(HEMA) Film. Int. J. Electrochem. Sci. 2012, 7, 4702-4715.

38. Labella, A.; Berbel, C.; Manchado, M.; Castro, D.; Borrego, J.J. Photobacterium Damselae Subsp. Damselae, an Emerging Pathogen Affecting New Cultured Marine Fish Species in Southern Spain. Recent Adv. Fish Farms 2011, 136-152.

39. Economou, V.; Gousia, P.; Kemenetzi, D.; Sakkas, H.; Papadopoulou, C. Microbial Quality and Histamine Producing Microflora Analysis of the Ice Used for Fish Preservation. J. Food Saf. 2016, 37, e12285. [CrossRef]

(C) 2017 by the authors. Licensee MDPI, Basel, Switzerland. This article is an open access article distributed under the terms and conditions of the Creative Commons Attribution (CC BY) license (http://creativecommons.org/licenses/by/4.0/). 